\title{
Spatial Dynamic Effects in the Colombian Health System
}

\author{
Leonardo Rodríguez-Pineda, Andrés Felipe Sánchez-Saldarriaga \\ and Helena María Cancelado-Carretero
}


Lecturas de Economía, 92 (enero-junio 2020), pp. 201-222

Leonardo Rodríguez-Pineda, Andrés Felipe Sánchez-Saldarriaga and Helena María Cancelado-Carretero

Spatial Dynamic Effects in the Colombian Health System

Abstract: We seek to understand if spatial dynamics affect the population in social, economic and health terms. To carry out this study, we propose the following two stages. In the first stage we try to understand the causes of high infant mortality in rural areas in comparison to the urban areas based on literature and the changes made to the Colombian health model. The second stage is a spatial econometric analysis of the variables of interest, where the CEDE database of the Universidad de los Andes is utilized. The findings of this study confirm the importance of the inclusion of spatial effects, which is a sign that the health dynamics of populations are interrelated. This spatial interdependence corroborates the suggestion from literature where proposing policies coordinate the system and consider local and neighboring populations. Also, municipal administrations require the need to consider mechanisms of interlocution whilst working with their peers and allow these factors to be included in the planning of political measures taken that affect health conditions. Finally, we confirm differences between the rural and urban performance.

Keywords: government expenditures and health; health behavior; government policy; regulation; public health; crosssectional models; spatial models; treatment effect models; quantile regressions.

JEL Classification: H51, I12, I18, C21.

Efectos de la dinámica espacial en el sistema de salud colombiano

Resumen: Buscamos entender si la dinámica espacial afecta a la población en términos sociales, económicos y de salud. Para llevar a cabo este estudio, proponemos dos etapas. En la primera, buscamos comprender, desde la literatura y los cambios realizados en el modelo de salud colombiano, las causas de la alta mortalidad infantil en las zonas rurales en comparación con las zonas urbanas. La segunda, es un análisis econométrico espacial de las variables de interés, donde se utiliza la base de datos CEDE de la Universidad de los Andes. Los resultados de este estudio confirman la importancia de la inclusión de efectos espaciales, lo cual es una señal de que la dinámica de salud de las poblaciones está interrelacionada. Esta interdependencia espacial corrobora la sugerencia de la literatura que propone que las políticas deben estar coordinadas y considerar poblaciones locales y vecinas. Además, las administraciones municipales deberían considerar mecanismos de interlocución, mientras trabajan con sus pares, y permitir que estos factores se incluyan en la planificación de las medidas políticas en temas de salud. Finalmente, confirmamos diferencias en áreas rurales y urbanas.

Palabras clave: gastos del gobierno y salud; comportamiento de salud; politica gubernamental; regulación; salud pública; modelos transversales; modelos espaciales; modelos de efectos de tratamiento; regresiones cuantiles.

Clasificación JEL: H51, I12, I18, C21.

Les effets de la dynamique spatiale sur le système de santé colombien

Résumé: Nous cherchons à comprendre si la dynamique spatiale affecte la population en termes sociaux, économiques et sanitaires. Pour réaliser cette étude, nous proposons deux étapes. Dans la première, nous cherchons à comprendre, à partir de la littérature et des changements apportés au modèle de santé colombien, les causes de la haute mortalité infantile dans le milieu rural par rapport aux milieux urbaines. La deuxième étape est une analyse économétrique spatiale des variables d'intérêt, à partir de la base de données CEDE de l'Université de los Andes. Les résultats confirment l'importance de la prise en compte des effets spatiaux, puisque les dynamiques de santé des populations sont interdépendantes. Cette interdépendance spatiale montre que les politiques doivent être coordonnées et doivent également prendre en compte l'avis des populations locales. En outre, les villes devraient envisager mécanismes de dialogue et permettre que les effets spatiaux soient inclus dans la planification des politiques de santé publique. Enfin, nous confirmons les differences dans les zones rurales et urbaines.

Mots clés: dépenses gouvernementales et de santé; comportement en matière de santé; politique gouvernementale; régulation; santé publique; modèles transversaux; modèles spatiaux; modèles d'effet de traitement; régressions quantiles. Classification JEL: H51, I12, I18, C21. 


\title{
Spatial Dynamic Effects in the Colombian Health System
}

\author{
Leonardo Rodríguez-Pineda $\mathbb{\circledR}^{\mathrm{a}}$, Andrés Felipe Sánchez-Saldarriaga $\mathbb{C}^{\mathrm{b}}$ \\ and Helena María Cancelado-Carretero $\mathbb{B}^{c}$
}

\begin{abstract}
-Introduction. -I. Colombian Health System Background. -II. The Applications of Spatial Analysis to our Topic. -III. Data. -IV. Methodology. -V. Results. -Conclusions. -References.
\end{abstract}

doi: 10.17533/udea.le.n92a07

Original manuscript received on 8 January 2019; final version accepted on 9 September 2019

\section{Introduction}

The performance of the Colombian health sector has been affected by different groups of endogenous and exogenous factors. Some of these are the lack of integration of all the network actors in the provision of the service, the lack of structure in the system with greater development of this caused in regions of dispersed rural areas, low availability of health services affecting the opportunity to receive medical attention and poor quality of care, adding to the increase in chronic diseases and aging of the population. These factors threaten the dream of universal coverage, continuity in the provision of health services and quality of the service provided. These situations have generated that the government and the health organizations look for alternatives to mitigate the impact or in their defect to eradicate the scourges, and their proposed solutions consider not only the economic

a Leonardo Rodriguez-Pineda: graduated from Eafit University, Colombia. Institutional postal code: 050021. E-mail: lrodriguep@eafit.edu.co

https://orcid.org/0000-0001-6532-1348

b Andrés Felipe Sánchez-Saldarriaga: graduated from Eafit University, Colombia. Institutional postal code: 050021. E-mail: afsanchezs@eafit.edu.co

https://orcid.org/0000-0001-6558-2089

c Helena María Cancelado-Carretero: Full time ICESI university professor. Eafit University, Colombia. Institutional postal code: 760031. E-mail: hcancela@icesi.edu.co

https://orcid.org/0000-0002-3411-1927 
factor, but in turn, the social factor seeking to respond to the basic needs of the population (Ministerio de Salud y Protección Social, 2016a).

Among the initiatives of the Pan American Health Organization (PAHO) is the idea of forming Integrated Health Services Networks (IHSN), which will allow health care to stop being fragmented, to integrate all the actors in the network and remove the loss of information or reprocessing. In addition, the IHSN focus on the rational and efficient use of available resources, which in turn focuses on the satisfaction of users of the health network (PAHO, 2010).

In the overall performance of the system, fragmentation manifests itself at the network level, such as: lack of coordination between the different levels and sites of care, duplication of services, idle installed capacity and less appropriate health services provided at the site. At user level such as: lack of access to services, loss of continuity of care and lack of consistency of services with the needs of users (PAHO, 2010).

Currently, national and international health goals are aligned with the Millennium Development Goals (MDGs). To carry out the development of these objectives, it is necessary to increase the efficient investment into health systems. Colombia's response to internal health needs and commitment to the MDGs are described in the Ten-Year Public Health Plan (PDSP in Spanish) 2012-2021. In the PDSP, the guidelines are defined to favor the articulation between the actors, the public and the private sectors in a way that guarantees the well-being and quality of life for Colombians. Specifically, the health risk management line of the PDSP, which includes actions such as quality management in care and administrative and technical coordination of services and plans.

Maternal childcare is considered one of the most important points in the development and articulation of health systems. The maternal and infant mortality rates are the indicators of the performance evaluation of the health network in this field. Although in Colombia progress has been made in reducing infant mortality rates, they are still high compared to developed countries. In addition to this, the highest proportion of deaths are concentrated in rural areas (Programa de las Naciones Unidas para el Desarrollo -PNUD-, 2015). 
The importance of the inclusion of spatial effects in the analysis varies regarding health issues. In cases of diseases and performance of health services, the demographic variables present an important correlation with the spatial, environmental and geographical conditions (Rusthon, 2003). Therefore, the inclusion of the spatial dynamics of geodemographic variables allows us to consider the spatial spillovers that affect the performance of health systems (Jeleskovic \& Schwanebeck, 2012).

Traditional analysis of infant mortality uses the data panel methodology, which does not consider the existence of spatial effects, and which are in fact present in the Colombian health situation, where the population needs to be mobilized between municipalities to obtain health services. As a result of this phenomena it is necessary to integrate the spatial effects in a spatial panel methodology.

\section{Colombian Health System Background}

We ask ourselves the following question from the PNUD (2015). Why are the desired goals in the maternal and childcare programs in Colombia not being met? We proposed some answers starting from the literature of maternal and childcare programs.

The desired goals in the maternal and childcare programs in Colombia are not being met due to misinformation or incomplete information that the users receive, affecting their opportunity to be attended, in addition to the lack of programs for the promotion and prevention of maternal and child health PNUD, 2015; Guerrero, Gallego, Becerril-Montekio \& Vásquez, 2011 and Ministerio de Salud y Protección Social, 2016b).

Not all pregnant women are guaranteed access to facilities of the maternal health care network, due to persistent problems of equity in their health affiliation and in accessibility to health services for the poorest population groups, unemployed population, ethnic and racial minorities and the displaced population. The outcome being that not all pregnant women have the opportunity of an appointment at the required time (Carrillo, 2007; 
Rodríguez-Pineda, Sánchez-Saldarriaga and Cancelado-Carretero: Spatial Dynamic Effects...

Maine, Akalin, Ward \& Kamara, 1997 and Escallon, Rodríguez-Pineda \& Rivera, 2015).

Moreover, pregnant mothers on different occasions are either not aware of having a problem or are delayed in making the decision to attend a health institution. These situations are associated with reasons of lack of information, cultural characteristics, in some cases, by the opposition of the spouse, economic difficulties or family problems, etc. (Carrillo, 2007 and Maine et al., 1997).

Not all strategies implemented by the health system to improve the adherence to prenatal controls with emphasis on the family inclusion have good results (Cáceres-Manrique, 2009 and Luján, 2010). The high rates of maternal mortality in Colombia are related to the non-guarantee given by the State of the right to health of Colombians due to the deficiency of adequacy of low complexity hospital services (Carrillo, 2007).

Another important aspect to highlight is the lack of training that mothers, relatives and companions have in the medical guidelines of the maternal health program. Institutions in charge of providing health services do not provide the information on time so that users can identify the possible symptoms of health complications that threaten the life of the pregnant mother (Maine et al., 1997 and Pazmiño \& Guzmán-Gómez, 2009). Also, the rate of assistance to prenatal controls by pregnant mothers is low, but the prevalence of dissatisfaction of some mothers continues with the health system (CáceresManrique, 2009).

Due to the aspect of the health service providers, the lack of timely and moderate hospital services for users is reflected, as well as the lack of opportunity to use laboratories to carry out medical tests and poorly designed care protocols or non-compliance (Vélez, Gallego \& Jaramillo, 2005).

There is a lack of medication, a need to increase the proportion of deliveries attended by doctors and the requirement for doctors to spend longer intervals of time to attend patients. On the other hand, there is the possibility of early detection of risk in pregnant women due to variability in early detection processes. Only one out of every two patients were fully 
examined, and gynecological examinations were not performed in many cases in the city of Cali (Pazmiño \& Guzmán-Gómez, 2009).

At this point, we begin to highlight the shortcomings in regulation and supervision of public and private actors participating in the system (Guerrero et al., 2011 and Donabedian, Wheeler \& Wyszewianski, 1982). We found that the proper coordination between health institutions and public institutions in charge of food security, basic sanitation and environmental vector control programs has been completely neglected, since none of these sectors considers these types of actions a priority. Also, the health sector has not led the previous initiative as its main concern has been the development of promoting health companies (EPS in Spanish), institutions providing services (IPS in Spanish) (Carrillo, 2007).

It is necessary to highlight that many cases of maternal deaths are associated with the lack of good quality health services and with the unsatisfied basic needs of some of the patients. This deficiency of good quality health services is directly affected by the leadership capacity of those in charge (Carrillo, 2007; Luján, 2010 and Donabedian, 1978).

Finally, we have found that, although the Colombian health system has sought to provide solutions to the problems that arise within the system, still no substantive solutions have been implemented that articulate the process and structure of the maternal and child health networks. It is necessary to use strategies such as integrated health service networks and the development of primary health care strategies without being disoriented from this approach, where all the network actors are considered as well as the problems of fragmentation and lack of alignment of global system objectives. The foregoing should be sought without leaving aside the empowerment of efficient coordination in health investment by the responsible actors.

\section{The Applications of Spatial Analysis to our Topic}

In the scientific literature we can find that spatial analysis has been used to understand the infant mortality phenomena. Some studies believe that a spatial modeling approach is important to produce reliable estimates in 
the infant mortality analysis (Gemperli, Vounatsou, Kleinschmidt, Lengeler \& Smith, 2004; and Barufi, Haddad \& Paez, 2012). Also, we can find evidence of the spatial analysis application in infant mortality in the United States (Rushton, Krishnamurty, Lolonis \& Song, 1996, and Banerjee, Wall \& Carlin, 2003), Africa (Gemperli et al., 2004; Kalipeni, 1993; and Balk, Pullum, Storeygard, Greenwell \& Neuman, 2004), Brazil (Barufi et al., 2012), France (Padilla et al., 2013) and throughout the rest of the world (Storeygard, Balk, Levy \& Deane, 2008).

The importance of the inclusion of spatial effects in the analysis varies regarding health issues. In cases of diseases and performance of health services, the demographic variables present an important correlation with the spatial, environmental and geographical conditions that face the population. Additionally, the spatial correlation of these variables is based on the hypothesis, in which contiguous areas are exposed to similar risks, for which the transmission effects are stronger in nearby geographical areas (Rusthon, 2003). On the other hand, the inclusion of spatial effects solves the problem of traditional estimates, which may present biases in their estimators due to the omission of spatial effects. Therefore, the inclusion of the spatial dynamics of geodemographic variables allows us to consider the spatial spillovers that affect the performance of health systems (Jeleskovic \& Schwanebeck, 2012).

The use of the spatial panel is justified, since it has been demonstrated that the health variables have a spatial dependence, which is due to the fact that spatial units make decisions that relate to the health of the locals and the inhabitants of the space. Also, health systems have a certain level of integration, since in many cases they provide services to foreign inhabitants who live in nearby areas (Baltagi, Moscone \& Santos, 2018). Due to this fact, the spatial panel allows incorporating the spatial and time factors that influence infant mortality.

This document proposes an empirical strategy at the municipal level, since considering this geographical unit, one can observe in greater detail the influence of the various factors and omit problems generated by presenting 
aggregate data in larger geographical units. However, this empirical methodology can present limitations due to the difficulty in obtaining data at this level of specificity and prevent analysis for long periods of time. Therefore, we propose the use of space panel for the period 2005-2009.

\section{Data}

We include the number of children under one-year old and dead in each municipality as a variable, together with the population conditions and the use of fiscal resources in water and health. The data used are between the years 2005-2009 for 556 municipalities and are based on the Center for Economic Development Studies (CEDE in Spanish) panel of the Universidad de los Andes (2014).

We take the dependent variable as the logarithm of the number of deaths of children under one year in each municipality (Death_minors). The explanatory variables were in three categories of population conditions, performance of health agencies and the use of fiscal resources; in the first category we can find the logarithm of the total population of the municipality (Population), the logarithm of the index that measures the proportion of the population of the municipality that lives in rural areas (Ind_rural), the logarithm of the total number of births in the municipality (Born) and the logarithm of the total number of deaths in the municipality (Deaths_total). In the category of performance of health agencies consists the logarithm of birth with low weight in the municipality (Born_lw) and the logarithm of the number of inhabitants of the municipality in the subsidized health regime (Subsidized). These variables are proxies of the performance of the health institutions in prevention and coverage. In the last category, there is the logarithm of the fiscal performance index that measures fiscal solvency, use of public budget and other aspects of the fiscal operation of the municipalities (Fiscal_perf), the logarithm of investment in local currency in water and sanitation at municipal level (Inves_sanit) and the logarithm of health investment in local monetary currency at the municipal level (Inves_health). 
The selection of control variables is based on the availability of municipal data and previous research, such as the one conducted by Gamper-Rabindran, Khana nd Timmins (2010). These show that population variables related to birth, mortality, population size and variables such as rural conditions and access to sewerage services have a significant impact on infant mortality rates.

\section{Methodology}

The empirical methodology proposed consists of two parts. Initially we must identify the existence of spatial patterns of the dependent variable through the Moran index and exploratory data analysis (ESDA). Next, we must develop an empirical specification of traditional panel and identify which is the most appropriate, to later perform the identification of the most appropriate spatial panel model (Torres-Preciado, Polanco-Gaytán \& TinocoZermeño, 2017).

The empirical specification proposed in this document is the following:

$$
\begin{gathered}
Y_{i t}=\rho \sum_{j=1}^{N} w_{i j} Y_{i t}+\beta X_{i t}+\varepsilon_{i t}, \\
\varepsilon_{i t}=\gamma \sum_{j=1}^{N} w_{i j} \varepsilon_{j t}+\mu_{i t},
\end{gathered}
$$

where $i$ denotes the municipalities and $t$ the year, $Y_{i t}$ denotes the dependent variable and $X_{i t}$ the group of explanatory variables. Also, $\rho \sum_{j=1}^{N} w_{i j} Y_{i t}$ and $\gamma \sum_{j=1}^{N} w_{i j} \varepsilon_{j t}$ refers to the spatial effects of the dependent variable and the errors respectively.

\section{Results}

The development in the empirical strategy used the sample of 556 municipalities which agglomerated around $80 \%$ of the total population of the country. Table 1 presents the descriptions of municipalities for each 
region's total population and number of deaths of children younger than one year in 2009. The municipalities of the sample are allocated in all regions of Colombia; however, it can be observed that the Andean and Pacific regions have the highest population concentration.

Table 1. Description of Municipalities

\begin{tabular}{lccc}
\hline Región & Municipalities & Population 2009 & Deaths of under 1 year 2009 \\
\hline Amazonía & 22 & 710.588 & 64 \\
Andina & 283 & 22.304 .051 & 822 \\
Caribe & 120 & 7.362 .243 & 377 \\
Orinoquía & 30 & 1.068 .361 & 69 \\
Pacífica & 101 & 6.201 .950 & 279 \\
\hline Total & $\mathbf{5 5 6}$ & $\mathbf{3 7 . 6 4 7 . 1 9 3}$ & $\mathbf{1 . 6 1 1}$ \\
\hline
\end{tabular}

Source: own elaboration with data from the CEDE Panel (2014).

Consequently, with this methodological approach, the first step consists of the identification of spatial effects. Table 2 presents the Moran's I statistic for the dependent variable for each of the years included in the panel. For the development of the Moran indices and the spatial regressions, a queentype contiguity matrix of order one is used, which allows us to capture the spatial relationship that exists between the municipalities and their immediate neighbors.

The results of Table 2 show that there is spatial dependence when the regression of the variable of interest is performed with all the regressors for each year. The ESDA is presented for the year 2005 and 2009, which correspond to the final and initial year of the panel. The maps presented in Figure 1 present the standard deviation maps for the child death variable and in these the existence of a spatial concentration of municipalities with similar levels in this variable can be observed. Additionally, the presence of the highest number of deaths of children under 1 year are consistent in time and spatial characteristics, because most of the municipalities with the highest level of this variable are allocated in the Northern area and coastal regions of Colombia. Figure 2 presents the LISA maps, which show the existence of 
Rodríguez-Pineda, Sánchez-Saldarriaga and Cancelado-Carretero: Spatial Dynamic Effects...

some spatial clusters for this variable, allocated in the Caribe region, which are considered zones with the greatest difficulties in health services, corruption and fiscal performance.

Table 2. Moran Test for Spatial Dependence

\begin{tabular}{ccc}
\hline Year & $\chi^{2}$ & Prob. $>\chi^{2}$ \\
\hline 2005 & 20,71 & 0,000 \\
2006 & 15,54 & 0,000 \\
2007 & 12,40 & 0,000 \\
2008 & 3,23 & 0,072 \\
2009 & 3,31 & 0,068 \\
\hline
\end{tabular}

Source: own elaboration with data from the CEDE Panel (2014).

Figure 1. Standard Deviation Maps

Panel A (2005)

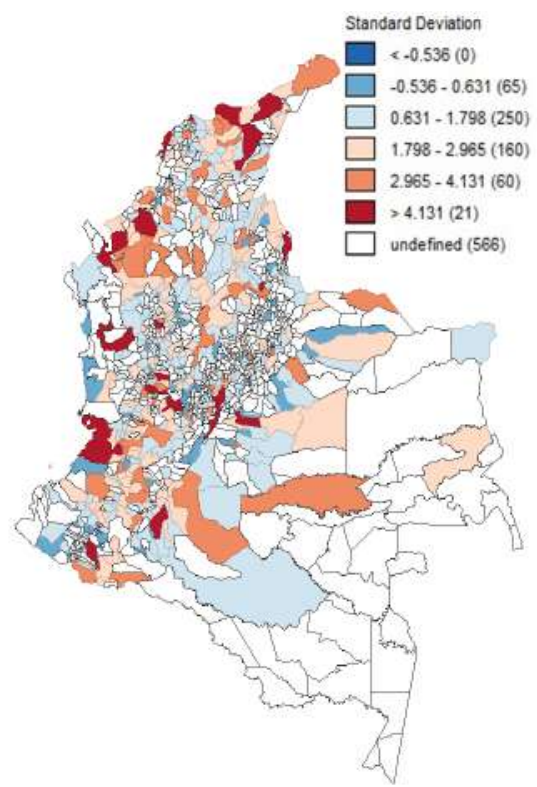

Panel B (2009)

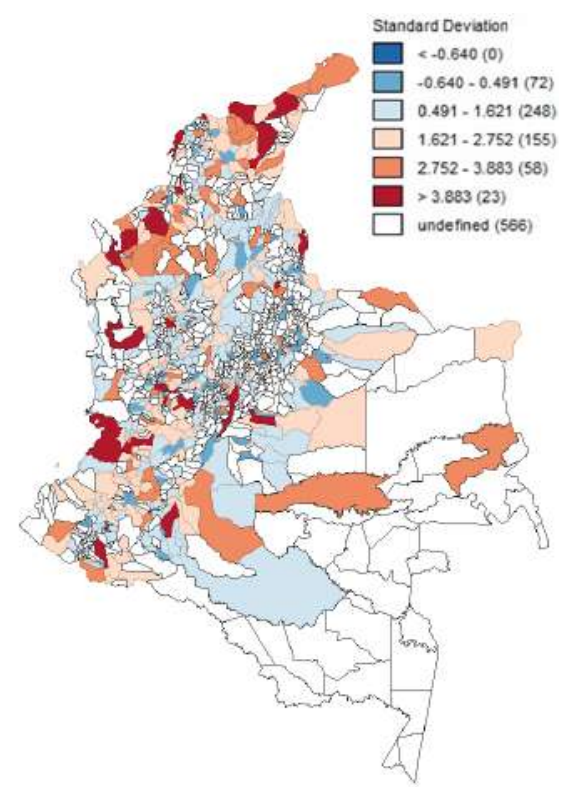

Source: own elaboration with data from the CEDE Panel (2014). 
Figure 2. LISA Maps

Panel A (2005)

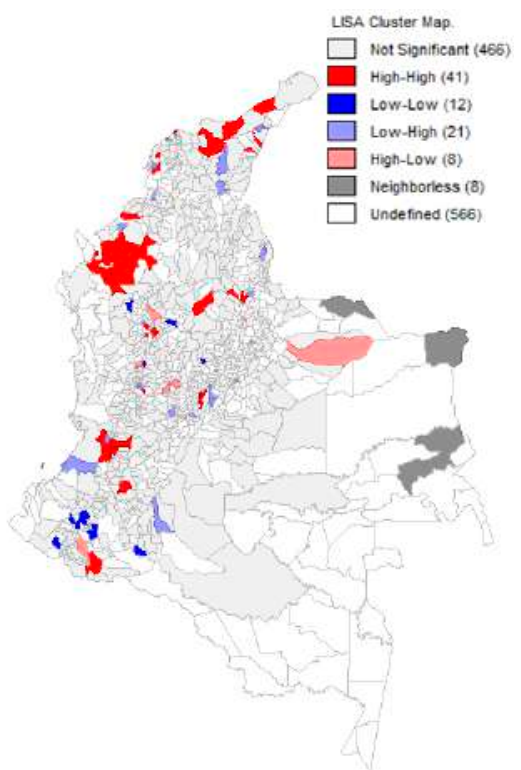

Panel B (2009)

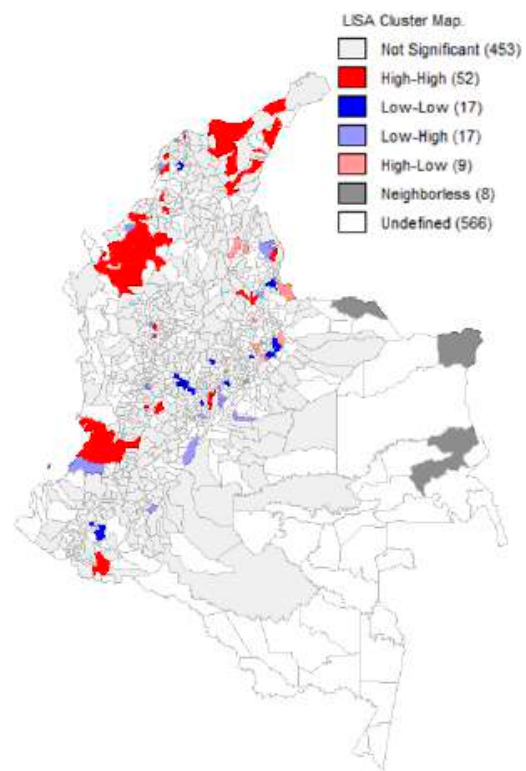

Source: own elaboration with data from the CEDE Panel (2014).

The previous technical arguments state that the inclusion of spatial effects is important in the analysis of health variables and that space plays an important role in its dynamics. It is important to point out that this document proposes that the most appropriate space empirical model should be the Spatial Autocorrelation model (SAC), as this model allows us to include the spatial effects of the endogenous variable and the spatial factors of the error term corresponding to the omitted variables, which in the present analysis is significant. This is because there are not enough explanatory variables at the municipal level to reduce this omission. Additionally, the inclusion of a more complex model such as the General Nested model is not adequate, since significance and accuracy are lost in the model (Elhorst, 2014).

To make the identification of the most suitable spatial panel model, estimates of the data panel models are initially made without considering the 
Rodríguez-Pineda, Sánchez-Saldarriaga and Cancelado-Carretero: Spatial Dynamic Effects...

spatial effects. Table 3 presents the results of the estimation of the pooled model by fixed effects and random effects. Then Table 4 presents the results of the tests that show that the most indicated for this case is the panel model with fixed effects.

Table 3. Pooled Estimates, Fixed Effects (FE) and Random Effects (RE)

\begin{tabular}{lccc}
\hline Variable & Pool & FE & RE \\
\hline Deaths_minors & & & \\
Population & $0,1279^{* * *}$ & $-1,3258^{* * *}$ & $0,1570^{* * *}$ \\
Ind_rural & $0,0463^{* * *}$ & $1,0915^{* * *}$ & $0,0700^{* * *}$ \\
Subsidized & $0,2366^{* * *}$ & $-0,11048^{*}$ & $0,1385^{* * *}$ \\
Born & $0,5410^{* * *}$ & $0,1965^{* *}$ & $0,5306^{* * *}$ \\
Born_lw & $0,1803^{* * *}$ & $0,1142^{* * *}$ & $0,1311^{* * *}$ \\
Deaths_total & $-0,0238$ & $0,6888^{* * *}$ & $0,0952^{* * *}$ \\
Fiscal_perf & $-0,6097^{* * *}$ & $-0,1106$ & $-0,5218^{* * *}$ \\
Inves_sanit & $0,02057^{* *}$ & 0,0138 & $0,0183^{* *}$ \\
Inves_health & $-0,0250^{* * *}$ & $-0,0101$ & $-0,02015^{* *}$ \\
Constant & $-2,9081^{* * *}$ & $12,9122^{* * *}$ & $-2,9680^{* * *}$ \\
\hline
\end{tabular}

Note: ${ }^{*} p<, 1 ;{ }^{* *} p<, 05 ;{ }^{* * *} p<, 01$.

Source: own elaboration with data from the CEDE Panel (2014).

From the previous results it can be pointed out that some relevant findings are found, such as the increase in health coverage by the subsidized regime for people in unfavorable conditions, which decreased infant mortality. Similar results also occur in the comparison between the fiscal performance and investment in health.

On the other hand, it is found that investment in water and sanitation has the opposite effect, which may be a sign of how slow and inefficient investment is in this area of Colombian municipalities.

Subsequently, the spatial panel estimates are made for the SAC, Spatial Autoregressive model (SAR), Spatial Error model (SEM) and Spatial Durbin model (SDM) and their respective Akaike Information Criteria (AIC), to 
observe which is the most indicated. The results of these spatial estimates are presented in Table 5, which confirm that the best specification is the corresponding one in the SAC model.

Table 4. Hausman Test

\begin{tabular}{lcccc}
\hline & \multicolumn{2}{c}{ Coefficients } & & \\
& Fixed effect & Random effect & Difference & S.E. \\
\hline Population & $-1,3258$ & 0,1570 & $-1,4829$ & 0,3329 \\
Ind_rural & 1,0915 & 0,07001 & 1,0215 & 0,3734 \\
Subsidized & $-0,1104$ & 0,1385 & $-0,2490$ & 0,0449 \\
Born & 0,1965 & 0,5306 & $-0,3341$ & 0,0583 \\
Born_lw & 0,1142 & 0,1311 & $-0,0169$ & 0,0171 \\
Deaths_total & 0,6888 & 0,0952 & 0,5935 & 0,0483 \\
Fiscal_perf & $-0,1106$ & $-0,5218$ & 0,4111 & 0,0684 \\
Inves_sanit & 0,0138 & 0,0183 & $-0,0045$ & 0,0025 \\
Inves_health & $-0,0101$ & $-0,0201$ & 0,0099 & 0,0019 \\
\hline Test: & Coefficient & p value & & \\
(FE-RE) $=0$ & 280,53 & 0 & & \\
\hline
\end{tabular}

Source: own elaboration with data from the CEDE Panel (2014).

The development of the empirical strategy in the previous section, supports the inclusion of spatial factors through the SAC model for the analysis of infant mortality at the municipal level. Table 6 presents in more detail the results of the estimation of the empirical specification in a spatial panel model SAC and Table 7 presents the direct, indirect and total effects of the model. In the results of the estimation of the SAC spatial model, it can be observed that there is a statistical significance of the spatial factors, both of the dependent variable in space, and of the term of spatial error, for which it is confirmed that inclusion is important of these effects within the analysis of health variables within the Colombian territory. It should be noted that there is a significance among some of the control variables, which is a sign that they are determining variables in the number of deaths of children under 1 year old at the municipal level. Additionally, although some coefficients lose 
Rodríguez-Pineda, Sánchez-Saldarriaga and Cancelado-Carretero: Spatial Dynamic Effects...

significance, the signs are still consistent with the previous results of the panel estimates for fixed effects.

Table 5. Spatial Panel Estimations

\begin{tabular}{|c|c|c|c|c|}
\hline Variable & SAR & SAC & SEM & SDM \\
\hline \multicolumn{5}{|l|}{ Deaths_minors } \\
\hline Population & $-1,310^{* * *}$ & $-1,250^{* * *}$ & $-1,320^{* * *}$ & $-1,101^{* * *}$ \\
\hline Ind_rural & $1,0564^{* * *}$ & $1,0241^{* * *}$ & $1,0746^{* * *}$ & 0,6200 \\
\hline Subsidized & $-0,1047^{*}$ & $-0,0843$ & $-0,1094^{*}$ & $-0,0288$ \\
\hline Born & $0,1923^{* *}$ & $0,1702^{* *}$ & $0,1965^{* *}$ & $0,1724^{* *}$ \\
\hline Born_lw & $0,1145^{* * *}$ & $0,1106^{* * *}$ & $0,1145^{* * *}$ & $0,1196^{* * *}$ \\
\hline Deaths_total & $0,6852^{* * *}$ & $0,6765^{* * *}$ & $0,6867^{* * *}$ & $0,6758^{* * *}$ \\
\hline Fiscal_perf & $-0,1045$ & $-0,1155$ & $-0,1061$ & $-0,0313$ \\
\hline Inves_sanit & 0,0135 & 0,0132 & 0,0137 & 0,0115 \\
\hline Inves_health & $-0,0098$ & $-0,0102$ & $-0,0099$ & $-0,0068$ \\
\hline \multicolumn{5}{|l|}{ Spatial } \\
\hline Deaths_minors & 0,0563 & $0,2802^{* * *}$ & & 0,0213 \\
\hline Spatial error & & $-0,2682^{* *}$ & 0,0297 & \\
\hline Population & & & & $-0,1851$ \\
\hline Ind_rural & & & & $1,7312^{*}$ \\
\hline Subsidized & & & & $-0,0376$ \\
\hline Born & & & & $-0,0209$ \\
\hline Born_lw & & & & $-0,0660$ \\
\hline Deaths_total & & & & $0,2982^{*}$ \\
\hline Fiscal_perf & & & & $-0,5675^{*}$ \\
\hline Inves_sanit & & & & 0,0106 \\
\hline Inves_health & & & & $-0,0321$ \\
\hline constant & $0,4423^{* * *}$ & $0,4385^{* * *}$ & $0,4425^{* * *}$ & $0,4406^{* * *}$ \\
\hline \multicolumn{5}{|l|}{ Statistics } \\
\hline AIC & $2.706,0755$ & $2.704,4176$ & $2.707,2603$ & $2.706,4151$ \\
\hline Observation & 556 & 556 & 556 & 556 \\
\hline
\end{tabular}

Note: ${ }^{*} p<, 1 ;{ }^{* *} p<, 05 ;{ }^{* * *} p<, 01$.

Source: own elaboration with data from the CEDE Panel (2014).

Also, it is important to highlight that the results of the estimations confirm the perception of vulnerability faced by rural populations and are met with precarious access and with high difficulties to the health system. The coefficient of the rurality index shows high sensitivity and positive 
relationship with the death of children under 1 year. It can also be observed that the significance and the positive sign of the spatial correlation of the dependent variable, confirm that the spatial factors of the death of children

Table 6. Effects

\begin{tabular}{|c|c|c|}
\hline Variable & $\mathrm{dy} / \mathrm{dx}$ & Std. \\
\hline \multicolumn{3}{|l|}{ Direct } \\
\hline Population & $-1,261^{* * *}$ & 0,3247 \\
\hline Ind_rural & $1,0331^{* * *}$ & 0,3620 \\
\hline Subsidized & $-0,0850$ & 0,0556 \\
\hline Born & $0,1717^{* *}$ & 0,0752 \\
\hline Born_lw & $0,1116^{* * *}$ & 0,0329 \\
\hline Deaths_total & $0,6825^{* * *}$ & 0,0575 \\
\hline Fiscal_perf & $-0,1165$ & 0,1102 \\
\hline Inves_sanit & 0,0133 & 0,0086 \\
\hline Inves_health & $-0,0103$ & 0,0083 \\
\hline \multicolumn{3}{|l|}{ Indirect } \\
\hline Population & $-0,2724^{* *}$ & 0,1377 \\
\hline Ind_rural & $0,2231^{*}$ & 0,1249 \\
\hline Subsidized & $-0,0183$ & 0,0132 \\
\hline Born & $0,0371^{*}$ & 0,0219 \\
\hline Born_lw & $0,0241^{*}$ & 0,0129 \\
\hline Deaths_total & $0,1474^{* *}$ & 0,0686 \\
\hline Fiscal_perf & $-0,0251$ & 0,0267 \\
\hline Inves_sanit & 0,0028 & 0,0022 \\
\hline Inves_health & $-0,0022$ & 0,0020 \\
\hline \multicolumn{3}{|l|}{ Total } \\
\hline Population & $-1,533$ & 0,4010 \\
\hline Ind_rural & 1,2563 & 0,4443 \\
\hline Subsidized & $-0,1034^{*}$ & 0,0664 \\
\hline Born & $0,2088^{*}$ & 0,0906 \\
\hline Born_lw & $0,1357^{*}$ & 0,0409 \\
\hline Deaths_total & $0,8299^{*}$ & 0,0937 \\
\hline Fiscal_perf & $-0,1417$ & 0,1347 \\
\hline Inves_sanit & 0,0162 & 0,0105 \\
\hline Inves_health & $-0,0125$ & 0,0101 \\
\hline
\end{tabular}

Note: ${ }^{*} p<, 1 ;{ }^{* *} p<, 05 ;{ }^{* * *} p<, 01$.

Source: own elaboration with data from the CEDE Panel (2014). 
under 1 year tend to spread to nearby areas, approving the argument that public health decisions affect local people and nearby areas. On the other hand, the significance of the error term indicates that there are omitted variables that could not be included due to limitations in the information.

Also, the results presented a negative relationship with the population variable, which is because with a higher level of population in a municipality there can be generated a rise in the fiscal income and better public goods for the local population, reducing the movability to other areas for health services. For the other population variables, it is a positive relationship. Moreover, an increase in newborns with low weight has a positive relationship with the death of children under 1 year. This is a consequence of the deficiencies of the health system and insufficiency in prevention.

The direct and indirect effects show that the demographic variables produce spatial spillovers, which may be related to the interaction and social mobility that exists among the inhabitants of nearby areas, demonstrating that space is of real importance when analyzing phenomena with dependence space.

\section{Conclusions}

Within this document, we have tried to observe through traditional panel and spatial panel estimates, the effect of demographic, fiscal and health coverage variables on infant mortality in children under one year, which can be considered as data giving better understanding of the efficiency of health systems. The inclusion of spatial effects within the present analysis allows us to integrate some spatial dynamics that affects the population in social, economic and health terms, among others.

The results of the empirical strategy made in the document allow us to partially evaluate the health conditions of the Colombian population and its relationship with other variables of interest at the municipal level. In addition, these findings confirm the importance of the inclusion of spatial effects, which is a sign that the health dynamics of populations are interrelated, since the conditions of the Colombian health system imply a mobility of the 
population between areas in order to obtain the health services needed. This is because not all areas of the territory have entities that provide specialized services, and in some cases, they only have access to the most basic services.

This spatial interdependence indicates that policies should be implemented to better coordinate the system and that both local and surrounding populations should be considered when designing health policies. This requires municipal administrations to consider mechanisms for interlocution and to work with their peers, resulting in the inclusion of these factors into the planning of measures that affect health conditions.

The foregoing shows us indications of how the guiding and intervening capacity, directed by the network for the period of time analyzed, is not being carried out in an articulated manner. It would be expected that with the new plans of the Ministry of Health, the performance of the Colombian health network could be improved because the objectives of the Ministry of Health would then be aligned for the entire network.

Also, it is important to point out that, despite the limited information that could be used for the development of the empirical methodology, the results provide good initial information to undertake future research. Allowing the inclusion of a greater number of variables and at the same time being more specific in the territory of analysis, such as major metropolitan areas of Colombian territory which have more information and allow in-depth study to understand the dynamics related to the efficiency of the health system and child mortality.

For future research, it would be important to include advanced econometric techniques for the inclusion of the special characteristic of dichotomous variables. Additionally, it would be relevant to have in account the identification of some proxy variables for the inclusion of more Amazonia and Orinoquia regions municipalities, as these zones have a larger extension in the country, but lower population levels. Also, these areas have the highest problems in health services and their inhabitants are isolated. 
Rodríguez-Pineda, Sánchez-Saldarriaga and Cancelado-Carretero: Spatial Dynamic Effects...

\section{References}

Balk, D., Pullum, T., Storeygard, A., Greenwell, F. \& Neuman, M. (2004). A spatial analysis of childhood mortality in West Africa. Population. Space and Place, 10(3), 175-216.

Baltagi, B. H., Moscone, F. \& Santos, R. (2018). Spatial Health Econometrics. Health Econometrics (Contributions to Economic Analysis, Volume 294), Emerald Publishing Limited.

Banerjee, S., Wall, M. M. \& Carlin, B. P. (2003). Frailty modeling for spatially correlated survival data, with application to infant mortality in Minnesota. Biostatistics, 4(1), 123-142.

Barufi, A. M., Haddad, E., \& Paez, A. (2012). Infant mortality in Brazil, 1980-2000: A spatial panel data analysis. BMC public health, 12(181).

Cáceres-Manrique, F. M. (2009). El control prenatal: una reflexión urgente. Revista Colombiana de Obstetricia y Ginecología, 60(2), 165-170.

Carrillo, A. (2007). Mortalidad materna en Colombia: reflexiones en torno a la situación y la política pública durante la última década. Revista Ciencias de la Salud, 5(2), 72-85.

Donabedian, A. (1978). The quality of medical care. Science, 200(4344), 856-864.

Donabedian, A., Wheeler, J. R. \& Wyszewianski, L. (1982). Quality, cost, and health: an integrative model. Medical Care, 20(10), 975-992.

Elhorst, J. P. (2014). Linear spatial dependence models for cross-section data. Spatial Econometrics (pp. 5-36). Berlin, Heidelberg: Springer.

Escallon, V. J., Rodríguez-Pineda, L. \& Rivera, L. (2015). Modelo del comportamiento de las listas de espera en pacientes de cirugías electivas en el sistema de salud colombiano. XIII Congreso latinoamericano de Dinámica de Sistemas. Cartagena de indias. 
Gamper-Rabindran, S., Khan, S. \& Timmins, C. (2010). The impact of piped water provision on infant mortality in Brazil: A quantile panel data approach. Journal of Development Economics, 92(2), 188-200.

Gemperli, A., Vounatsou, P., Kleinschmidt, I. B., Lengeler, C. \& Smith, T. (2004). Spatial patterns of infant mortality in Mali: the effect of malaria endemicity. American Journal of Epidemiology, 159(1), 64-72.

Guerrero, R., Gallego, A. I., Becerril-Montekio, V. \& Vásquez, J. (2011). Sistema de salud de Colombia. Salud Pública de México, 53, 144-155.

Jeleskovic, V. \& Schwanebeck, B. (2012). Assessment of a spatial panel model for the efficiency analysis of the heterogonous healthcare systems in the world. Joint Discussion Paper Series in Economics, (18).

Kalipeni, E. (1993). Determinants of infant mortality in Malawi: a spatial perspective. Social Science \& Medicine, 37(2), 183-198.

Luján, F. J. (2010). Luces y sombras de la reforma de la salud en Colombia: Ley 100 de 1993. Bogotá: Assalud.

Maine, D., Akalin, M. Z., Ward, V. M. \& Kamara, A. (1997). Diseño y evaluación de programas para mortalidad materna. New York: Centro para la Población y Salud Familiar. Facultad de Salud Pública, Universidad de Columbia.

Ministerio de Salud y Protección Social (2016a). Análisis de Situación de Salud. Colombia, 2015. Bogotá: Imprenta Nacional de Colombia.

Ministerio de Salud y Protección Social (2016b). Politica de atención integral en salud. Un sistema de salud al servicio de la gente. Recuperado de: https: //www.minsalud.gov.co/sites/rid/Lists/BibliotecaDigital/RIDE/DE/mo delo-pais-2016.pdf

Pan American Health Organization (PAHO) (28 de Mayo de 2010). La Renovación de la Atención primaria de Salud en las Américas. Redes Integradas de Servicio de Salud: Conceptos, Opciones de Politica y hoja de Ruta para su implementación en las Ámericas, 4. Washington D.C. Recuperado de: https://www.paho.org/uru/index.php?option=co 
m_docman\&view=download \&alias=145-redes-integradas-de-servicios -de-salud-aps-n4\&category_slug=publicaciones-sistemas-y-servicios-desalud $\&$ Itemid $=307$

Padilla, C. M., Deguen, S., Lalloue, B., Blanchard, O., Beaugard, C., Troude, F., Vieira, V. M. (2013). Cluster analysis of social and environment inequalities of infant mortality. A spatial study in small areas revealed by local disease mapping in France. Science of The Total Environment, 454-455(1), 433-441.

Pazmiño de Osorio, S. \& Guzmán-Gómez, N. (2009). Control prenatal y su impacto en la mortalidad materna: Análisis de una tendencia. Revista Colombiana de Obstetricia y Ginecología, 60(1), 12-18.

Programa de las Naciones Unidas para el Desarrollo (PNUD) (2015). Objetivos de desarrollo del Milenio. Bogotá: Nuevas Ediciones S.A.

Rushton, G. (2003). Public health, GIS, and spatial analytic tools. Annual Review of Public Health, 24(1), 43-56.

Rushton, G., Krishnamurty R., Krishnamurti, D., Lolonis, P. \& Song, H. (1996). The spatial relationship between infant mortality and birth defect rates in a US city. Statistics in Medicine, 15(18), 1907-1919.

Storeygard, A., Balk, D., Levy, M. \& Deane, G. (2008). The global distribution of infant mortality: a subnational spatial view. Population, Space and Place, 14(3), 209-229.

Torres-Preciado, V. H., Polanco-Gaytán, M. \& Tinoco-Zermeño, M. A. (2017). Crime and regional economic growth in Mexico: a spatial perspective. Papers in Regional Science, 96 (3), 477-494.

Vélez Álvarez, G. A., Gallego Vélez, L. I. \& Jaramillo Posada, D. C. (2005). Modelo de análisis de la muerte materna: Camino para la supervivencia. En Gallego, L., Gómez, J. y Escobar, A. Modelos para el análisis de la mortalidad materna y perinatal (33-44). Medellín: Secretaría de Salud, Alcaldía de Medellín. 